\title{
Long-wavelength UVA enhances UVB-induced cell death in cultured keratinocytes: DSB formation and suppressed survival pathway
}

\author{
Yuko Ibuki $^{1}$ (D) Yukako Komaki $^{1} \cdot$ Guang Yang $^{1} \cdot$ Tatsushi Toyooka $^{2}$
}

Received: 9 March 2021 / Accepted: 28 April 2021 / Published online: 12 May 2021

(c) The Author(s), under exclusive licence to European Photochemistry Association, European Society for Photobiology 2021

\begin{abstract}
Solar UV radiation consists of both UVA and UVB. The wavelength-specific molecular responses to UV radiation have been studied, but the interaction between UVA and UVB has not been well understood. In this study, we found that long-wavelength UVA, UVA1, augmented UVB-induced cell death, and examined the underlying mechanisms. Human keratinocytes HaCaT were exposed to UVA1, followed by UVB irradiation. Irradiation by UVA1 alone showed no effect on cell survival, whereas the UVA1 pre-irradiation remarkably enhanced UVB-induced cell death. UVA1 delayed the repair of pyrimidine dimers formed by UVB and the accumulation of nucleotide excision repair (NER) proteins to damaged sites. Gap synthesis during NER was also decreased, suggesting that UVA1 delayed NER, and unrepaired pyrimidine dimers and single-strand breaks generated in the process of NER were left behind. Accumulation of this unrepaired DNA damage might have led to the formation of DNA double-strand breaks (DSBs), as was detected using gel electrophoresis analysis and phosphorylated histone $\mathrm{H} 2 \mathrm{AX}$ assay. Combined exposure enhanced the ATM-Chk2 signaling pathway, but not the ATR-Chk1 pathway, confirming the enhanced formation of DSBs. Moreover, UVA1 suppressed the UVB-induced phosphorylation of Akt, a survival signal pathway. These results indicated that UVA1 influenced the repair of UVB-induced DNA damage, which resulted in the formation of DSBs and enhanced cell death, suggesting the risk of simultaneous exposure to high doses of UVA1 and UVB.
\end{abstract}

\section{Graphic abstract}

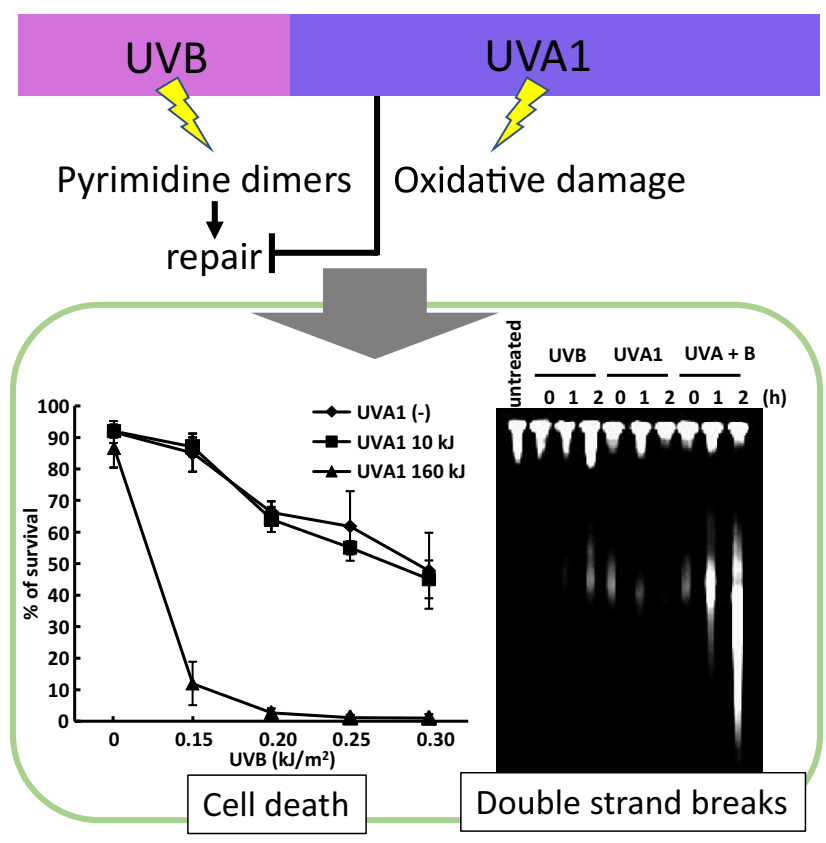

Extended author information available on the last page of the article 
Keywords UVA $\cdot$ DNA double-strand breaks $\cdot \gamma$-H2AX $\cdot$ Pyrimidine dimers $\cdot$ Nucleotide excision repair $\cdot$ Akt

$\begin{array}{ll}\text { Abbreviations } \\ \text { ATM } & \text { Ataxia telangiectasia-mutated } \\ \text { ATR } & \text { ATM and Rad3-related } \\ \text { BER } & \text { Base excision repair } \\ \text { BSA } & \text { Bovine serum albumin } \\ \text { BSFGE } & \text { Biased sinusoidal field gel electrophoresis } \\ \text { CPDs } & \text { Cyclobutane pyrimidine dimers } \\ \text { DSBs } & \text { Double-strand breaks } \\ \text { DMEM } & \text { Dulbecco's modified Eagle's medium } \\ \text { EdU } & \text { 5-Ethynyl-2'-deoxyuridine } \\ \text { FBS } & \text { Fetal bovine serum } \\ \gamma \text {-H2AX } & \text { Phosphorylated histone H2AX } \\ \text { NER } & \text { Nucleotide excision repair } \\ \text { 8-oxodG } & \text { 8-Oxo-7,8-dihydro-2'-deoxyguanosine } \\ \text { PI } & \text { Propidium iodide } \\ \text { PI3K } & \text { Phosphatidylinositol-3 kinase } \\ \text { 6-4PPs } & \text { Pyrimidine (6-4) pyrimidone photoproducts } \\ \text { SSBs } & \text { Single strand breaks } \\ \text { ssDNA } & \text { Single-stranded DNA } \\ \text { UV } & \text { Ultraviolet } \\ \text { UVR } & \text { UV radiation }\end{array}$

\section{Introduction}

Solar UV radiation (UVR) is well known to cause various adverse consequences on human health including the generation of skin cancer, aging, and skin's immune suppression. Terrestrial UVR comprises $<5 \%$ UVB $(\sim 295-315$ $\mathrm{nm})$ and $>95 \%$ UVA $(315-400 \mathrm{~nm})$, the majority $(\sim 75 \%)$ of which is UVA1 (340-400 nm). Many researches of UVinduced adverse effects on the skin have historically focused on UVB and recently UVA as well. The WHO International Agency for Research on Cancer Monograph classified both UVB and UVA as a Class I carcinogen [1].

UVB radiation, a major cause of skin cancer after solar UV exposure, is absorbed by DNA, giving rise to dimeric photoproducts between adjacent pyrimidine bases. Two types of bulky modifications are produced, namely cyclobutane pyrimidine dimers (CPDs) and pyrimidine (6-4) pyrimidone photoproducts (6-4PPs) [2]. The repair of 6-4PPs is more efficient than that of CPDs [3]. Cell proliferation was not prevented in the presence of unrepaired CPDs, suggesting that unrepaired CPDs have a role in the mutagenic activity of UVB [4]. CPDs are the major lesions produced by UVA irradiation as well [5, 6]. UVA photons directly absorbed by DNA form CPDs without detectable formation of 6-4PPs, which generates different mutation spectra from that caused by UVB $[7,8]$. UVA radiation-induced oxidation via photosensitization forms oxidative DNA damage, like 8-oxo-7,8-dihydro-2'-deoxyguanosine (8-oxodG), which is not a major cause of mutation after UVA radiation [9]. Furthermore, UVA-induced reactive oxygen and nitrogen species contribute to sustained CPD generation after irradiation in the presence of melanin [10]. UVA simultaneously cause protein oxidation, increasing genotoxicity and mutagenicity of sunlight [11].

The ability of UVA and UVB to induce DNA doublestrand breaks (DSBs) is also reported [12-14]. DSBs are the most deleterious form of DNA lesions and failure to repair them can result in loss of genetic information or cell death. In general, neither UVB nor UVA are expected to directly induce DSBs, and replication-dependent formation of DSBs is largely accepted $[14,15]$. The collapse of replication forks at unrepaired CPDs generated DSBs, which can be assumed from the accumulation of phosphorylated histone $\mathrm{H} 2 \mathrm{AX}(\gamma-\mathrm{H} 2 \mathrm{AX})$ foci at $\mathrm{S}$ phase of cell cycle [15, 16]. On the other hand, replication-independent formation is also reported. DSBs can be generated by the formation of clustered oxidative DNA lesions, when simultaneous excision of nearby lesions in opposing DNA strands is executed by base excision repair (BER) [17, 18]. The group of Rapp $[12,13]$ reported that the repair of bi-stranded, oxidative, clustered DNA lesions resulted in DSBs independent of replication after UVA irradiation. In UVB radiation, the gaps of single-stranded DNA (ssDNA) would form via NER of pyrimidine dimers in addition to secondary DNA strand breaks by the collapse of replication forks at unrepaired pyrimidine dimers. The resulting ssDNA and the loaded NER proteins also generate $\gamma$-H2AX [19, 20]. These results led us to postulate that combined exposure to UVA and UVB has the possibility to form a variety of DNA damage directly and indirectly; however, the combined exposure is not well studied even though sunlight contains both UVA and UVB, to which humans are exposed simultaneously.

Courdavault et al. [21] showed that CPDs induced by UVA were slightly less efficiently repaired than those formed by UVB. In addition, the rate of repair of CPDs formed after combined exposure (exposure to UVA, and subsequently to UVB) was significantly lower than CPDs formed by UVB irradiation alone. UVB-induced CPDs are well-known major cause of skin cancer, but the contribution of UVA to UVBinduced carcinogenesis is controversial [22]. Co-irradiation with relatively higher doses of UVA tended to increase UVB-induced cancer [23, 24]. Conversely, UVA close to daily exposure doses delayed UVB tumorigenesis [25]. Increasing UVA dose ratio to UVB protected skins from erythema and immunosuppression [26], and formation of sunburn cells [27]. These studies indicate that the UVA has 
opposite roles to mitigate or augment UVB-induced damage as a function of UVA dose and that combined effects of UVA and UVB warrants greater attention since simultaneous exposure to UVA and UVB is unavoidable.

In this study, we found that UVA1 itself, even if the doses are in excess of daily exposure level, induced no cell death in cultured keratinocytes, but showed remarkable cell death by combination with UVB. The underlying mechanism was investigated focusing on DNA damage formation and repair.

\section{Materials and methods}

\subsection{Cell culture}

The immortalized human keratinocyte cell line, HaCaT was kindly provided by Dr. Norbert Fusening (German Cancer Research Center). The cells were cultured in Dulbecco's modified Eagle's medium (DMEM) supplemented with $10 \%$ fetal bovine serum (FBS, HyClone Laboratories, Inc., South Logan, UT, USA) and 100 units/ml of penicillin/streptomycin at $37{ }^{\circ} \mathrm{C}$ in an atmosphere of $5 \% \mathrm{CO}_{2}$. To ensure the uniformity of cells for experiments, cells were periodically checked for the morphology under a microscope and doubling time by cell counting when cells were passed to other dishes.

\subsection{UVA1 and/or UVB radiation}

Exponentially growing cells cultured in DMEM containing $10 \%$ FBS were washed with low serum DMEM ( $0.5 \%$ FBS), further cultured in low serum DMEM for $24 \mathrm{~h}$ to minimize the influence of cell proliferation. Immediately before UV irradiation, the medium was changed to PBS containing calcium and magnesium, followed by further culturing in low serum DMEM. A medium change was also performed in untreated cells.

The radiation source of UVA1 was made up of six $60-\mathrm{cm}$ fluorescent tubes (main emission wavelength, $369 \mathrm{~nm}$, Hitachi 20 W FL20S-BL, Tokyo, Japan) held in a reflective batten $14 \mathrm{~cm}$ above the irradiation table surface. A commercial irradiation device was used for radiation source of UVB (main emission wavelength, $312 \mathrm{~nm}$, Atto Co., Ltd., Tokyo, Japan). The wavelength characteristics of UVA1 and UVB reconstructed from manufacturing data are shown in Supplementary Fig. 1. The irradiance was measured using a radiometer (Atto Co., Ltd., Tokyo, Japan) with UVA and UVB detectors (Atto Co., Ltd., Tokyo, Japan). The irradiation rates of UVA1 and UVB were 80 and $24 \mathrm{~kJ} / \mathrm{m}^{2} / \mathrm{h}$, respectively.

\subsection{Cell viability assay}

Cells were exposed to UVA1 and/or UVB, and further cultured in low serum DMEM for $24 \mathrm{~h}$. The irradiated cells were harvested using trypsin $(0.050 \%)$-EDTA $(0.025 \%)$ solution and then suspended in PBS. Trypan blue solution $(0.3 \%)$ was added to the cell suspension $(1: 1)$ for the discrimination of dead cells. More than 400 cells per sample were counted under the microscope.

\subsection{Determination of caspase-3 activity}

Caspase-3 activity was measured using a direct assay in cell lysates as previously described [28]. Briefly, following incubation for up to $8 \mathrm{~h}$ after exposure to UVA1 and/or UVB, the cells were lysed in lysis buffer $(10 \mathrm{mM}$ Tris- $\mathrm{HCl}$, pH 7.5, $130 \mathrm{mM} \mathrm{NaCl}, 1 \%$ Triton X-100, $10 \mathrm{mM} \mathrm{Na}_{4} \mathrm{P}_{2} \mathrm{O}_{7}$, and $10 \mathrm{mM} \mathrm{Na}_{2} \mathrm{HPO}_{4}$ ). Aliquots of cell lysate were incubated in reaction buffer (20 mM HEPES and 10\% glycerol) in the presence of Ac-DEVD-MCA $(250 \mu \mathrm{M}$, Peptide Inst. Inc., Japan) for $1 \mathrm{~h}$ at $37^{\circ} \mathrm{C}$. The amounts of fluorogenic MCA moiety released were measured using a spectrofluorometer (FL4500, Hitachi, Tokyo, Japan) (ex. $380 \mathrm{~nm}$, em. $460 \mathrm{~nm}$ ). The fluorescence intensity was converted to $\mu$ moles of MCA released using the standard curve of 7-amino-4-methylcoumarin.

\subsection{ELISA for pyrimidine dimers}

DNA of UVA1 and/or UVB exposed cells was purified using a QIAamp Blood Kit (Qiagen, Hilden, Germany). DNA was denatured by boiling for $10 \mathrm{~min}$, and then added (10 $\mathrm{ng} /$ well) to a polyvinylchloride 96-well plate pre-coated with protamine sulfate $(0.003 \%)$. After blocking with FBS (2\% in PBS), samples were incubated with primary antibodies against 6-4PPs (NM-DND-002, clone 64M-2) (1:1500) (Cosmo Bio Ltd.) and CPDs (NM-DND-001, clone TDM-2) (1:3000) (Cosmo Bio Ltd.), and then with the biotin- $\mathrm{F}\left(\mathrm{ab}^{\prime}\right)_{2}$ fragment of anti-mouse IgG (Zymed Laboratories, Inc.) (1:2000). Peroxidase-Streptavidin (Zymed Laboratories, Inc.) $(1: 10,000)$ was added, and a peroxidase reaction was performed using $o$-phenylene diamine $(0.4 \mathrm{mg} / \mathrm{mL})$ in the presence of $0.006 \% \mathrm{H}_{2} \mathrm{O}_{2}$. The reaction was stopped by the addition of $\mathrm{H}_{2} \mathrm{SO}_{4}(2 \mathrm{M})$, and absorbance at $492 \mathrm{~nm}$ was measured by a spectrophotometer.

\subsection{Local irradiation and immunofluorescent staining}

Cells cultured on 10-mm $\phi$ glass (Matsunami Glass Ind., Ltd., Osaka, Japan) were exposed to UVA1, then irradiated with $\mathrm{UVC}\left(0.1 \mathrm{~kJ} / \mathrm{m}^{2}\right)$ (main emission wavelength, 254 
nm, Atto Co. Ltd., Tokyo, Japan) through a polycarbonate isopore membrane filter (pore size: $3 \mu \mathrm{m}$ ) (Millipore Co., Darmstadt, Germany). UVC, the wavelength of which is shorter than UVB, was used because it only passes through the pores in the filter and pyrimidine dimers are generated within localized areas of the cell nucleus [29]. After being incubated for a predetermined period $(0-48 \mathrm{~h})$ to allow for the repair of pyrimidine dimers, cells were fixed with 5\% formalin (Wako Pure Chemical, Ind., Ltd., Osaka, Japan), permeabilized with $2 \%$ Triton X-100 in PBS, and further treated with $2 \mathrm{~N} \mathrm{HCl}$ if stained against pyrimidine dimers. Cells were incubated with primary antibodies against 6-4PPs (1:600), CPDs (1:600) (Cosmo Bio Ltd.), XPG (sc-13563) (1:200), and TFIIH (sc-293) (1:200) (Santa Cruz Biotechnology, Inc., Santa Cruz, CA, USA) diluted in $0.2 \%$ Triton $\mathrm{X}-100$ and $1 \%$ bovine serum albumin (BSA) in PBS, followed by secondary antibodies conjugated with FITC or CY5 $^{\mathrm{TM}}$ (Jackson ImmunoResearch, Inc., West Grove, PA, USA). The nucleus was stained with propidium iodide (PI) $(1 \mu \mathrm{g} / \mathrm{mL})$. Images were acquired with a fluorescence microscope (BX51, Olympus Optical Co., Ltd., Tokyo, Japan). More than 150 cells per sample were counted in randomly taken images ( 5 pictures), and the percentages of cells with foci were calculated. The number of foci per cell was not counted because it depended on the random distribution of pores in the filter.

\subsection{5-Ethynyl-2'-deoxyuridine (EdU) assay}

The gap-filling after excision of nucleotides containing pyrimidine dimers was determined by Click-iT ${ }^{\mathrm{TM}}$ Plus EdU Cell Proliferation Kit for Imaging (Invitrogen, Carlsbad, CA, USA). Briefly, cells cultured on 10-mm $\phi$ glass were exposed to UVA1, followed by local UVC-irradiation as described above. They were cultured in the presence of $8 \mu \mathrm{M}$ EdU for $30 \mathrm{~min}$, and fixed with 5\% formalin in PBS for 15 min, followed by permeabilization with $0.5 \%$ Triton X-100 in PBS for 20 min. Click-iT ${ }^{\mathrm{TM}}$ reaction buffer containing Alexa Fluor ${ }^{\circledR} 488$ picolyl azide was added and the glasses were left at room temperature for $30 \mathrm{~min}$.

For the confirmation of UVC-irradiated area, the cells were treated with $2 \mathrm{~N} \mathrm{HCl}$. They were incubated with primary antibody against CPDs diluted in $0.2 \%$ Triton X-100 and $1 \% \mathrm{BSA}$, followed by secondary antibody conjugated with CY5 ${ }^{\text {TM }}$. The nucleus was stained with Hoechst ${ }^{\circledR} 33342$ $(10 \mu \mathrm{g} / \mathrm{mL})$. Images were acquired with a fluorescence microscope. The images were randomly taken (5 pictures), and the EdU fluorescent intensity of each focus over CPD focus in nuclei was measured using Image $\mathrm{J}$ ver. 1.52a.

\subsection{Biased sinusoidal field gel electrophoresis (BSFGE) analysis}

Cells exposed to UVA1 and/or UVB were harvested with trypsin-EDTA $(0.05 \%)$ solution and solidified in $1 \%$ lowmelting agarose (Lonza Rockland, Inc., Rockland, ME, USA). Solidified sample gels were incubated with lysis buffer $(0.5 \mathrm{mg} / \mathrm{mL}$ proteinase $\mathrm{K}$ dissolved in $1 \%$ sodium $N$-lauroyl sarcosinate in $0.5 \mathrm{M}$ EDTA, $10 \mathrm{mM}$ Tris-HCl, $\mathrm{pH}$ 8.0) in the shaker at $50{ }^{\circ} \mathrm{C}$ for $24 \mathrm{~h}$. DNA was separated by $0.8 \%$ agarose gel with a BSFGE system (Atto Co. Ltd., Tokyo, Japan) in $0.5 \times$ TBE buffer $(45 \mathrm{mM}$ Tris- $\mathrm{HCl}, 45$ $\mathrm{mM}$ boric acid, and $1 \mathrm{mM}$ EDTA, $\mathrm{pH} 8.2$ ) for $32 \mathrm{~h}$ at $20^{\circ} \mathrm{C}$. The biased sinusoidal electric field was applied at DC $30 \mathrm{~V}$ and $\mathrm{AC} 198 \mathrm{~V}$ at the linear frequency gradient from 0.001 $\mathrm{Hz}$ (initial) to $0.005 \mathrm{~Hz}$ (final). The gel was stained with ethidium bromide and photographed using a transilluminator (Gel DOC XR; Bio-Rad Laboratories, Inc., Hercules, CA, USA).

\subsection{Immunofluorescent staining for $\mathrm{Y}-\mathrm{H} 2 \mathrm{AX}$}

Cells cultured on 10-mm $\phi$ glass (Matsunami Glass Ind., Ltd., Osaka, Japan) were exposed to UVA1 and/or UVB. They were cultured up to $2 \mathrm{~h}$ and immunofluorescent staining for $\gamma-\mathrm{H} 2 \mathrm{AX}$ was performed as described above. Used primary antibody for $\gamma-\mathrm{H} 2 \mathrm{AX}$ was made by Millipore (05636) and secondary antibody conjugated with FITC was from Jackson ImmunoResearch, Inc. The images were randomly taken (5 pictures), and the fluorescent intensity of nuclei were calculated using Image J ver. 1.52a.

\subsection{Western blotting}

Cells exposed to UVA1 and/or UVB were washed and harvested by scraping in lysis buffer $(100 \mathrm{mM}$ Tris- $\mathrm{HCl}(\mathrm{pH}$ 8.0), $50 \mathrm{mM}$ EDTA, $0.5 \%$ Triton X-100). They were sonicated for $30 \mathrm{~s}$ once, mixed with an equal volume of $2 \times$ sample buffer (0.1 M Tris- $\mathrm{HCl}$ (pH 6.8), 4\% SDS, 20\% glycerol, $12 \%$ 2-mercaptoethanol, $0.004 \%$ bromophenol blue) and boiled for $5 \mathrm{~min}$. Proteins were separated by $10-15 \%$ polyacrylamide gels and transferred to polyvinylidene fluoride membranes. After blocking with $0.2 \%$ skim milk, membranes were incubated with primary antibodies (1:1000) against $\gamma$-H2AX (07-164), phosphorylated ATM (p-ATM) (05-740), ATM (05-513) (Millipore Co., Darmstadt, Germany), phosphorylated ATR (p-ATR) (2853), ATR (2790), phosphorylated Chk1 (p-Chk1) (2348), Chk1 (2360), phosphorylated Chk2 (p-Chk2) (2661), Chk2 (2662), phosphorylated Akt (p-Akt) (9271) and Akt (9272) (Cell Signaling Technology, Inc., Danvers, MA) overnight at $4^{\circ} \mathrm{C}$, and then incubated with secondary antibody conjugated with horseradish peroxidase (Jackson ImmunoResearch, Inc.) for $2 \mathrm{~h}$. 
Protein expression was visualized with an enhanced chemiluminescence plus detection kit (GE Healthcare, Buckinghamshire, UK).

\subsection{Statistical analysis}

All experiments were repeated two to three times. Data are presented as the mean \pm SD. In immunofluorescent staining experiments, all slides were blinded to treatments when scoring slides. Data were analyzed by Student's $t$ test for comparisons between groups. Multiple comparisons were performed by one-way ANOVA with Bonferroni-corrected post hoc $t$ tests.

\section{Results}

\subsection{UVA1 enhances UVB-induced cell death}

HaCaT cells were irradiated with UVA1, then immediately with UVB. UVB induced dose-dependent cell death, which was not changed by pre-exposure to $10 \mathrm{~kJ} / \mathrm{m}^{2} \mathrm{UVA} 1$ (Fig. 1a). On the other hand, while high dose of UVA1 (160 $\mathrm{kJ} / \mathrm{m}^{2}$ ) itself only showed slight cell death, it drastically enhanced the UVB-induced death. This UVA1 dose ratio to UVB is much higher than that of natural sunlight [30]. Timedependent cell death after UVB irradiation $\left(0.2 \mathrm{~kJ} / \mathrm{m}^{2}\right)$ was also clearly enhanced by pre-exposure to UVA1 $\left(120 \mathrm{~kJ} / \mathrm{m}^{2}\right)$ (Fig. 1b). The significant increase in cell death was observed $4 \mathrm{~h}$ after coexposure. Even when the order of UVA1 and UVB irradiation was reversed, the enhanced cell death after coexposure was similar (Supplementary Fig. 2), suggesting that the enhanced cell death was caused by the combined effect of UVA1 and UVB irradiation, not by hypersensitization to UVB irradiation by UVA1.

In order to clarify whether the increase of cell death was due to induction of apoptosis, caspase-3 activity, a typical apoptosis marker, was determined (Fig. 1c). Caspase-3 activity remarkably increased from $4 \mathrm{~h}$ after UVB irradiation, and reached a plateau at $6-8 \mathrm{~h}$. UVA1 pre-exposure unexpectedly decreased the UVB-induced caspase- 3 activation. The decrease was UVA1-dose dependent (Fig. 1d). Annexin $\mathrm{V}$ analysis showed that the decrease of apoptosis activity was due to the induction of necrosis (Supplementary Fig. 3). UVA1 pre-irradiation shifted the predominant mode of cell death from UVB-induced apoptosis (Annexin $\mathrm{V}$ positive and $\mathrm{PI}$ negative) to necrosis (Annexin $\mathrm{V}$ positive and PI positive).

The enhanced cell death was most remarkable when UVB irradiation was performed immediately after UVA1 irradiation, and gradually attenuated as the time interval from UVB irradiation to UVA1 irradiation was extended
(Supplementary Fig. 4). In the case of UVB irradiation 6 $\mathrm{h}$ after UVA1 irradiation, the enhanced cell death was not observed any more.

\subsection{UVA1 delays the nucleotide excision and gap filling}

The formation of pyrimidine dimers can cause a lethal damage depending on the amounts. 6-4PPs and CPDs were determined by ELISA and immunofluorescent staining after local irradiation (Fig. 2). In ELISA (Fig. 2a), 6-4PPs were mostly repaired by $240 \mathrm{~min}$ after UVB irradiation, but significantly more unrepaired 6-4PPs remained when cells were irradiated with UVA1 immediately before UVB irradiation. CPDs were about $50 \%$ repaired at $12 \mathrm{~h}$ after UVB irradiation and preirradiation of UVA1 delayed the repair. Similar results were obtained using local irradiation methods (Fig. 2b). Local UVC irradiation using a micropore filter generated 6-4PPs and CPDs foci. The 6-4PP foci disappeared $90 \mathrm{~min}$ after UVC irradiation, but about $20 \%$ of the cells had unrepaired 6-4PPs when pre-irradiated with UVA1. However, the foci were completely repaired at $120 \mathrm{~min}$ regardless of the UVA1 irradiation. The delayed repair of the CPDs was similarly observed at 24 and $48 \mathrm{~h}$ after UVC irradiation.

To repair both pyrimidine dimers, NER proteins must accumulate to the damaged sites. We visualized the movement of NER proteins, TFIIH, XPG and XPA in locally UVirradiated cells when repair took place (Fig. 3a and Supplementary Fig. 5). We detected foci of TFIIH and XPG (Fig. 3a), and XPA (Supplementary Fig. 5) 5 min after local UVC irradiation, demonstrating the accumulation of NER proteins at DNA lesions. The accumulated proteins were released again at 30 and $60 \mathrm{~min}$ after irradiation. Cells preirradiated with UVA1 showed the weaker recruitment of repair proteins at $5 \mathrm{~min}$. This suppressed recruitment continued until $30 \mathrm{~min}$ and the releases of XPG and XPA were observed at $60 \mathrm{~min}$.

In ELISA and immunofluorescent staining in Fig. 2, we were able to examine the excision of nucleotides containing pyrimidine dimers, but not the repair completion by gap filling. Next, the gap-filling after nucleotide excision was determined using EdU assay. As the proliferative cells show high fluorescence with or without gap filling, we used local irradiation methods and the uptake of EdU accompanying complemental DNA synthesis in the irradiated area was determined (Fig. 3b). Pre-irradiation of UVA1 suppressed the gap-filling dose-dependently.

\subsection{DSBs formation after coexposure to UVA1 and UVB}

DSBs are the most serious DNA damage and known to be also produced after UVA or UVB irradiation [12-14]. We 

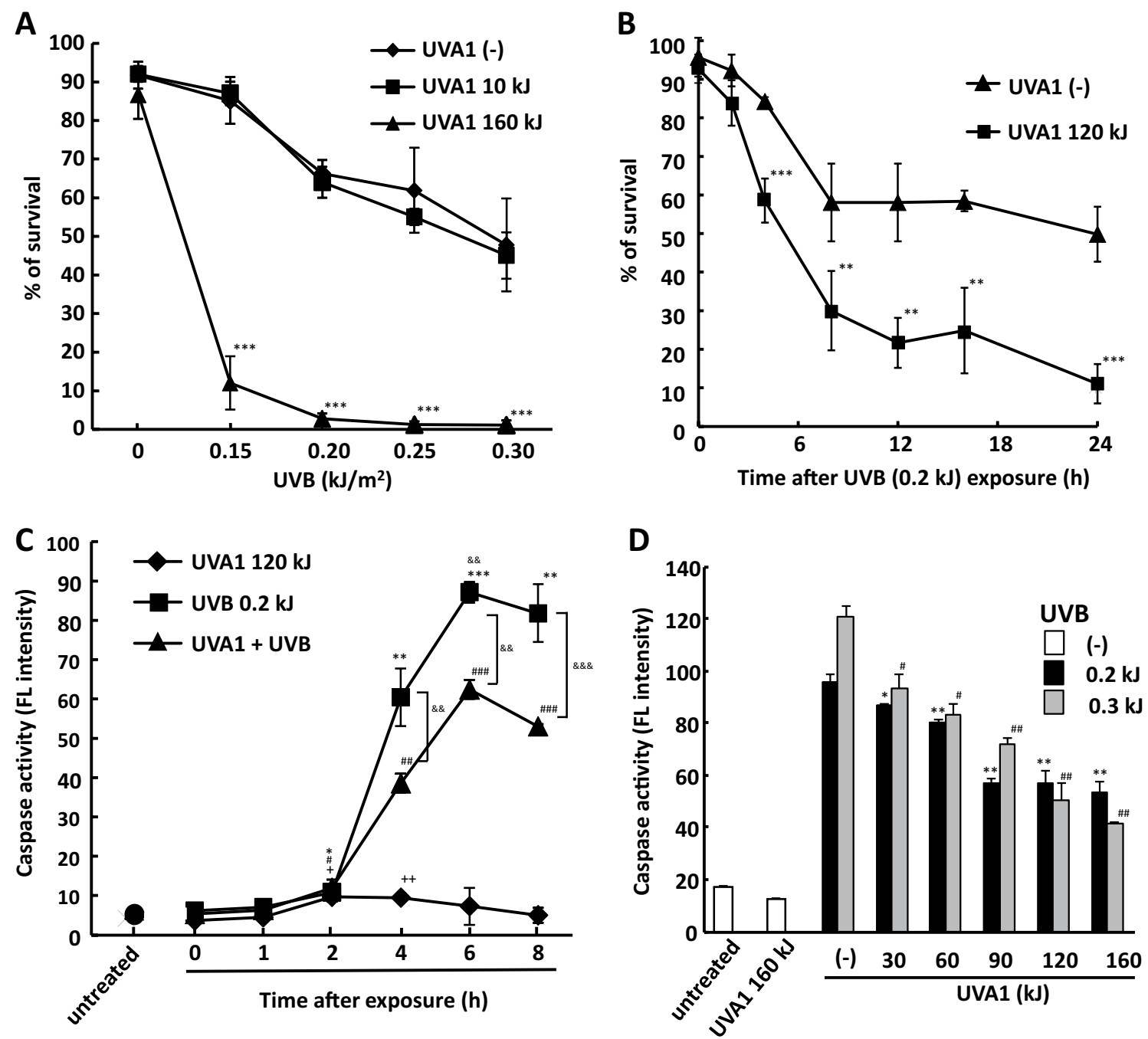

Fig. 1 UVA1 augments UVB-induced cell death. a Survival after exposure to UVA1 and UVB. HaCaT cells cultured in low serum DMEM were irradiated with UVA1 $\left(10\right.$ or $\left.160 \mathrm{~kJ} / \mathrm{m}^{2}\right)$, followed by UVB irradiation (up to $0.3 \mathrm{~kJ} / \mathrm{m}^{2}$ ). After further culturing for $24 \mathrm{~h}$, cell survival was assessed using the trypan blue assay $(n=4)$. $* * * p<0.001$ (vs. UVA1 $160 \mathrm{~kJ}$ ). b Time-dependent survival after exposure to UVA1 and UVB. HaCaT cells were irradiated with UVA1 $\left(120 \mathrm{~kJ} / \mathrm{m}^{2}\right)$, followed by UVB irradiation $\left(0.2 \mathrm{~kJ} / \mathrm{m}^{2}\right)$. The cells were cultured for predetermined periods and the trypan blue assay was performed $(n=4) . * * p<0.01, * * * p<0.001$ (UVA1 (-) vs. UVA1 $120 \mathrm{~kJ}$ ). c Time-dependent caspase-3 activity after exposure to UVA1 and UVB. HaCaT cells were irradiated with UVA1 (120

attempted to detect DSBs after coexposure to UVA1 and UVB using BSFGE (Fig. 4). BSFGE is a gel electrophoresis similar with pulse-field gel electrophoresis, and used to evaluate large DNA fragments. Cleaved DNA can migrate into the gel and is retained in the gel if the fragment size is long enough. If the DNA fragments are too short like apoptotic ladder DNA at a few hundred bps, they run off the gel and thus will not be detected. We chose to limit the time-course experiment up to $2 \mathrm{~h}$ because drastic cell death
$\left.\mathrm{kJ} / \mathrm{m}^{2}\right)$, followed by UVB irradiation $\left(0.2 \mathrm{~kJ} / \mathrm{m}^{2}\right)$. Cells were lysed and an aliquot of cell lysate ( $25 \mu \mathrm{g}$ proteins) was added in reaction buffer containing $250 \mu \mathrm{M}$ fluorogenic substrate, Ac-DEVD-MCA. The fluorescence intensity was converted to $\mu$ mols of MCA using the standard curve of 7-amino-4-methylcoumarin $(n=4) .{ }^{*,+\#} p<0.05$,

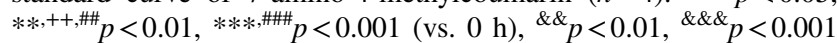
(UVB vs. UVA1 plus UVB). d UVA1-dose-dependent change of caspase- 3 activity after exposure to UVA1 and UVB. HaCaT cells were irradiated with UVA1 (up to $160 \mathrm{~kJ} / \mathrm{m}^{2}$ ), followed by UVB irradiation $\left(0.2\right.$ or $\left.0.3 \mathrm{~kJ} / \mathrm{m}^{2}\right)$. Cells were cultured for $6 \mathrm{~h}$ and lysed for caspase- 3 assay $(n=4) .{ }^{* \#} p<0.05, * *, \# p<0.01$ (vs. UVA1 $(-)$ )

was detected from $4 \mathrm{~h}$ as is shown in Fig. $1 \mathrm{~b}$ and we wished to avoid the interference from apoptosis-derived large DNA fragments. Very slight DSB formation was detected after individual irradiation. UVB irradiation immediately after UVA1 irradiation formed remarkable numbers of DSBs, which increased time- (Fig. 4a) and UVB dose- (Fig. 4b) dependently. In Supplementary Fig. 4, the time interval from UVB irradiation to UVA1 irradiation gradually attenuated the enhanced cytotoxic effect of the combined exposure. As 

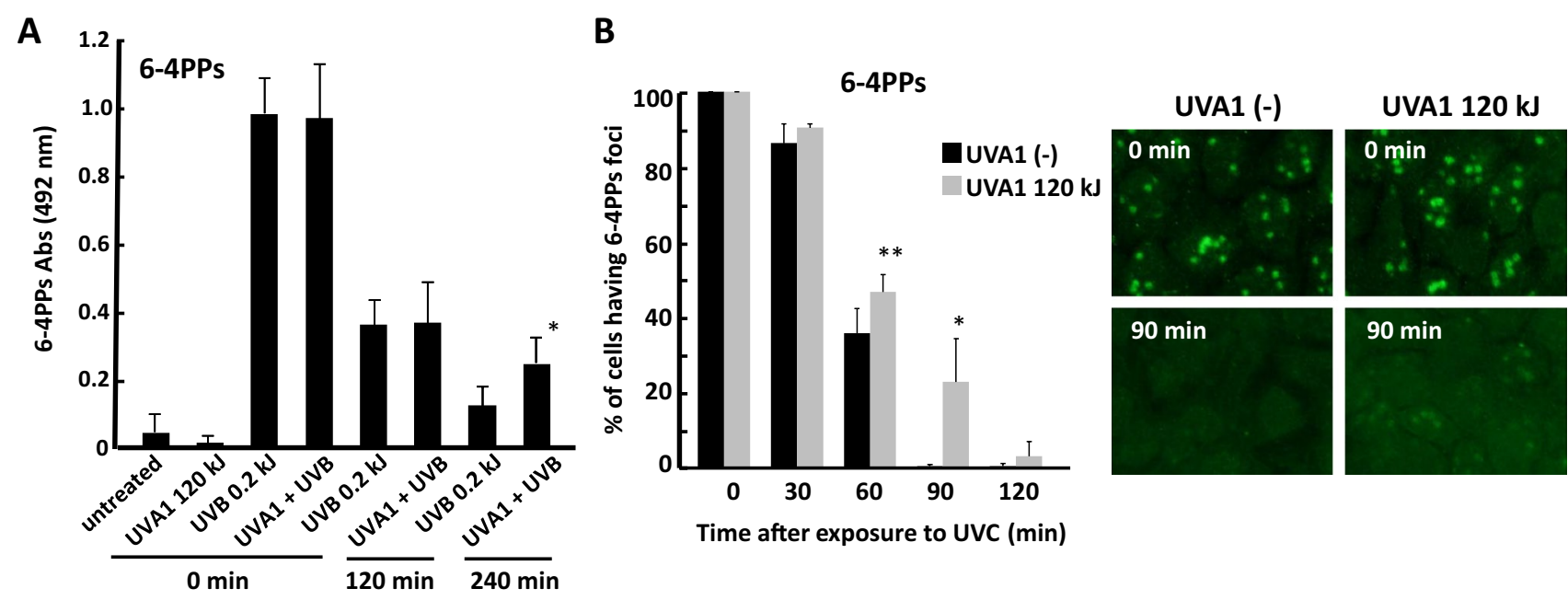

$90 \mathrm{~min}$
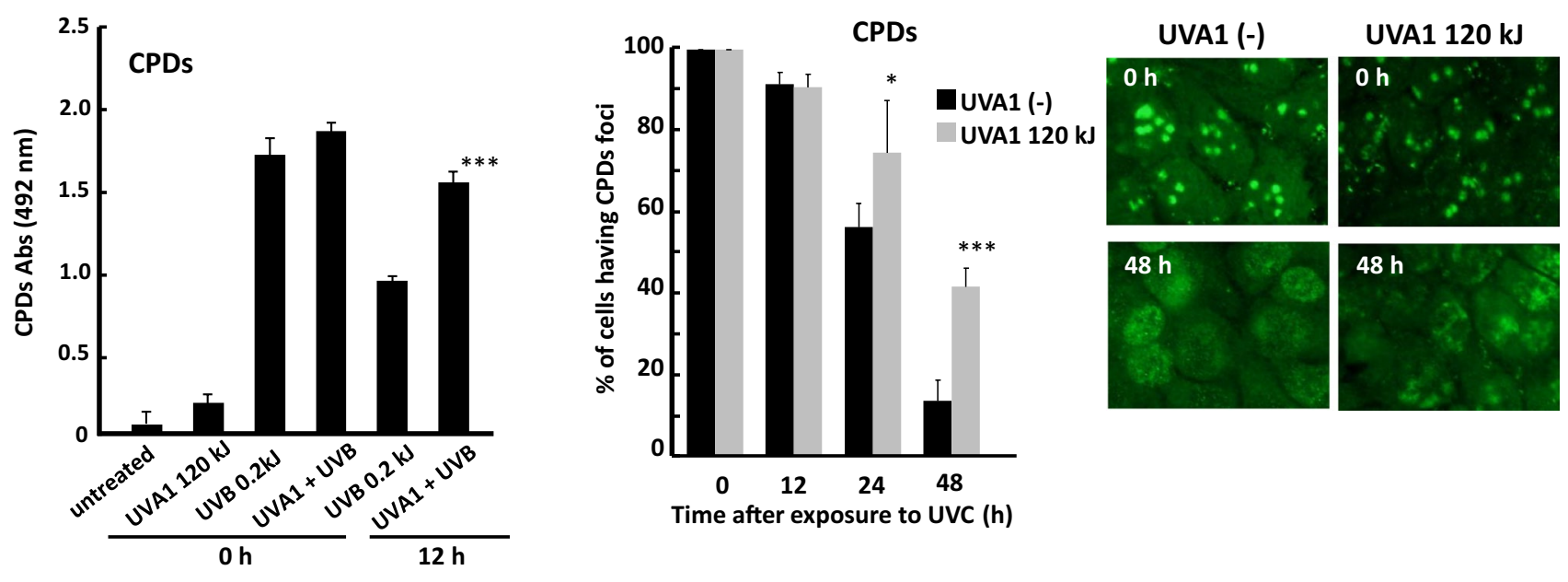

Fig. 2 UVA1 inhibits the repair of UVB-induced pyrimidine dimers. a Determination of 6-4PPs and CPDs using ELISA. HaCaT cells cultured in low serum DMEM were irradiated with UVA1 $(120 \mathrm{~kJ} /$ $\mathrm{m}^{2}$ ), followed by UVB irradiation $\left(0.2 \mathrm{~kJ} / \mathrm{m}^{2}\right)$. After cultured for predetermined times, the formation and repair of 6-4PPs and CPDs were assessed using ELISA $(n=4)$. $* p<0.05, * * * p<0.001$ (UVB vs. UVA1 plus UVB). b Evaluation of 6-4PPs and CPDs repair using local UV-irradiation method. HaCaT cells were irradiated with UVA1

with that result, the time interval up to $4 \mathrm{~h}$ between UVA1 and UVB irradiation gradually decreased the formation of DSBs (Fig. 4c).

The formation of DSBs was further confirmed by the generation of $\gamma$-H2AX (Fig. 5). $\gamma$-H2AX is known to occur shortly after DSB formation, but also over time through repair and replication after the formation of oxidative DNA damage and pyrimidine dimers [15, 16, 31]. Clear $\gamma$-H2AX was induced time-dependently after individual irradiation (Fig. 5a, b and Supplementary Fig. 6). Coexposure further enhanced the phosphorylation in time- (Fig. 5a) and UVB dose- (Fig. 5b) dependent manners. $\gamma$-H2AX after irradiation with UVA1 and UVB was further examined using immunofluorescence staining (Fig. 5c). The fluorescence intensity $\left(120 \mathrm{~kJ} / \mathrm{m}^{2}\right)$, then exposed to UVC $\left(0.1 \mathrm{~kJ} / \mathrm{m}^{2}\right)$ locally with a filter (3 $\mu \mathrm{m}$ pore size). After an incubation for predetermined periods, immunofluorescence staining was performed for 6-4PPs and CPDs. The picture was taken randomly and the percentages of cells with 6-4PPs and CPDs positive foci were calculated [about 150 cells per sample were evaluated $(n=5)]$. $* p<0.05, * * p<0.01, * * * p<0.01$ (UVA1 (-) vs. UVA1 $120 \mathrm{~kJ}$ )

of each cell was calculated. Time-dependent $\gamma$-H2AX generation was observed after UVB irradiation, which was enhanced by UVA1 pre-irradiation, consistent with western blotting data of Fig. 5a. The difference of $\gamma$-H2AX induction between combined exposure and solo UVB exposure was rather slight compared to the dramatic enhancement of DSB formation as shown in Fig. 4. This might reflect the complexity of $\gamma-\mathrm{H} 2 \mathrm{AX}$ induction, that is, $\gamma-\mathrm{H} 2 \mathrm{AX}$ is caused by various pathways [31]. 

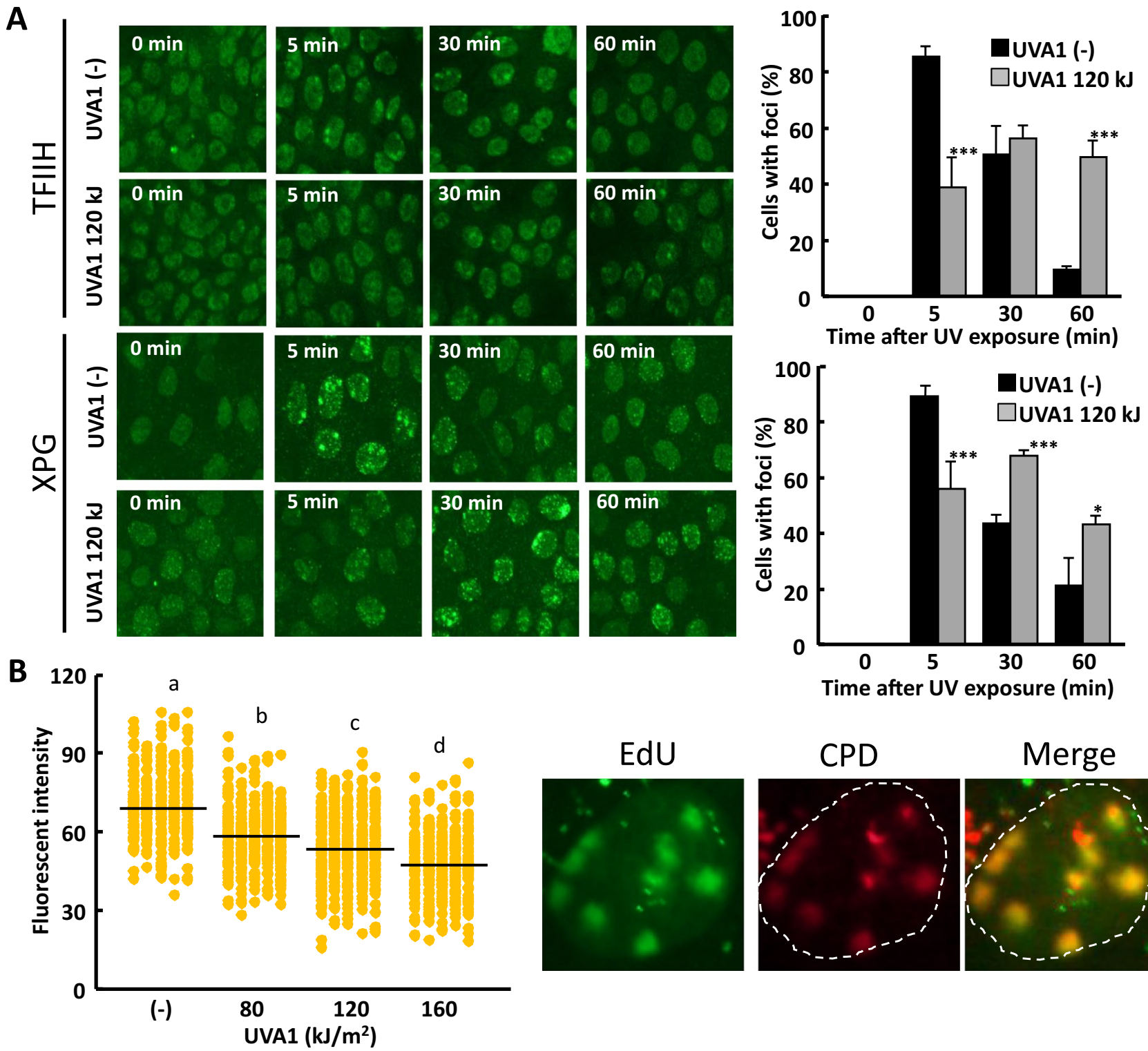

Fig. 3 UVA1 inhibits the recruitment of repair molecules and delays gap filling. a Accumulation of repair molecules to DNA-damaged sites. HaCaT cells cultured in low serum DMEM were irradiated with UVA1 $\left(120 \mathrm{~kJ} / \mathrm{m}^{2}\right)$, then exposed to UVC $\left(0.1 \mathrm{~kJ} / \mathrm{m}^{2}\right)$ locally with a filter ( $3 \mu \mathrm{m}$ pore size). After culture for up to $60 \mathrm{~min}$, immunofluorescence staining was performed for TFIIH and XPG. The picture was taken randomly and the percent of cells with positive foci for repair molecules was calculated [more than 150 cells per sample were evaluated $(n=5)] . * p<0.05, * * * p<0.001$ (UVA1 (-) vs. UVA1 $120 \mathrm{~kJ}$ ). b EdU assay. HaCaT cells were irradiated with UVA1 (up to $160 \mathrm{~kJ} /$ $\left.\mathrm{m}^{2}\right)$, then locally exposed to UVC $\left(0.1 \mathrm{~kJ} / \mathrm{m}^{2}\right)$. They were cultured in

\subsection{DNA damage response after UVA1 and UVB irradiation}

$\gamma-\mathrm{H} 2 \mathrm{AX}$ is caused by DSBs and other DNA damages via ataxia telangiectasia- mutated (ATM) or ATM and Rad3related (ATR) pathway [31]. p-ATM and p-ATR were

the presence of $8 \mu \mathrm{M}$ EdU for $30 \mathrm{~min}$, followed by Click-iT ${ }^{\mathrm{TM}}$ reaction according to the protocol provided by the company. For the confirmation of UVC-irradiated area, the cells were stained with antibody for CPDs. The nucleus was stained with Hoechst $33342(10 \mu \mathrm{g} /$ $\mathrm{mL}$ ). Images were acquired with a fluorescence microscope. The dotted lines in images show the Hoechst 33342 positive area (nucleus). The images were randomly taken ( 5 pictures), and the fluorescent intensity of each focus over CPDs focus in nuclei was calculated [about 150 cells per sample were evaluated $(n=5)$ ]. Different letters indicate significant differences between groups (post-hoc Student's $t$ test with Bonferroni correction, $p<0.05$ )

detected after UVA1 and UVB irradiation (Fig. 6a and Supplementary Fig. 7). UVB increased p-ATR, which was not changed by coexposure to UVA1. p-ATM was not induced by UVA1 or UVB alone but detected after coexposure.

The primary substrates of ATM and ATR are the checkpoint effector kinases Chk2 and Chk1, respectively [32]. The 
phosphorylation patterns of both kinases were consistent with those of ATM and ATR (Fig. 6b and Supplementary Fig. 7). Chk1 was phosphorylated by UVB irradiation, and slightly by UVA1 irradiation, yet irradiation with UVA1 before UVB irradiation did not enhance the phosphorylation. The phosphorylation of Chk2 was increased by individual irradiation and clearly enhanced by coexposure. These results suggested that both UVA1 and UVB irradiation activated both cell-cycle checkpoints, Chk1 and Chk2, and the coexposure enhanced the activation of ATM-Chk2 pathway, which was most likely caused by the formation of DSBs shown in Fig. 4.

\subsection{Survival signal after UVA1 and UVB irradiation}

Phosphatidylinositol-3 kinase (PI3K)/Akt pathway is a well-known survival signal. Phosphorylation of Akt was determined after coexposure to UVA1 and UVB (Fig. 7 and Supplementary Fig. 8). UVB solo-irradiation significantly enhanced Akt phosphorylation and UVA1 also showed slight activation. On the other hand, their combined irradiation decreased the phosphorylation, suggesting that UVA1 suppressed the UVB-induced survival signal pathway.

\section{Discussion}

In this study, we found that high doses of UVA1 itself showed no cell death but drastically augmented UVBinduced cell death. This phenomenon is thought to be attributable to multiple causes by the combined exposure to high doses of UVA1 and UVB as follows: (1) inhibition of some processes of NER, (2) formation of DSBs, and (3) decline of UVB-induced survival signaling. These are discussed in the order below.

There are several repair pathways for UVR-induced DNA damages such as NER and BER, which are common from prokaryotes to mammals. NER is the major pathway that repairs pyrimidine dimers formed by UVB [33]. Oxidized lesions are excised by the BER pathway [34]. Repair rates of 6-4PPs and CPDs induced by UVB were remarkably delayed by pre-irradiation with UVA1. This might be attributed to the inhibition of the recruitment of NER-related proteins to the damaged sites. Kimeswenger et al. [35] showed that UVA1 impaired the repair of UVB-induced CPDs in human melanocytes, probably due to oxidization of NER proteins by UVA1-mediated ROS. The group of Karran [36-39] also showed that UVA or UVA combined with photosensitizers
A

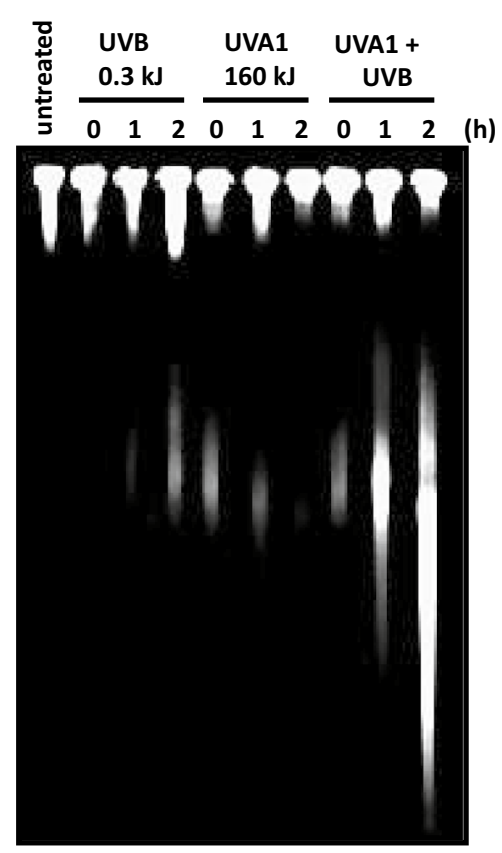

B

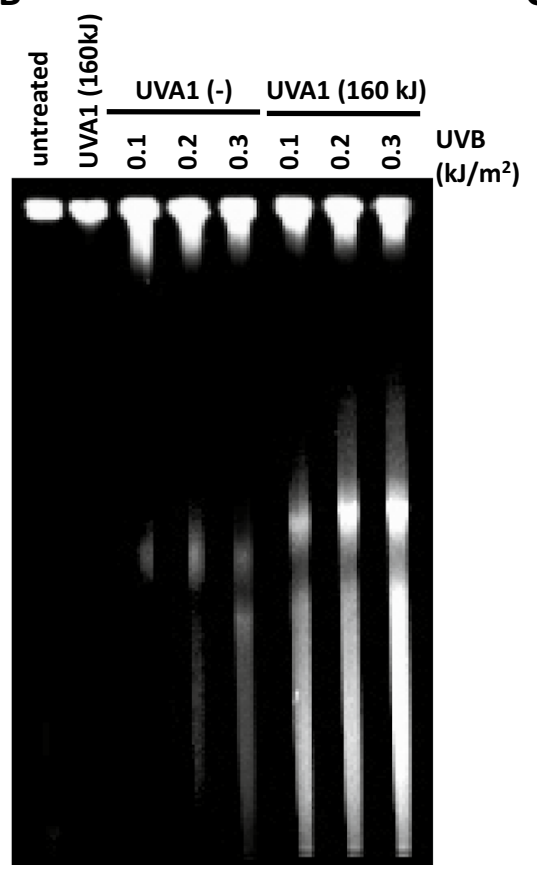

C

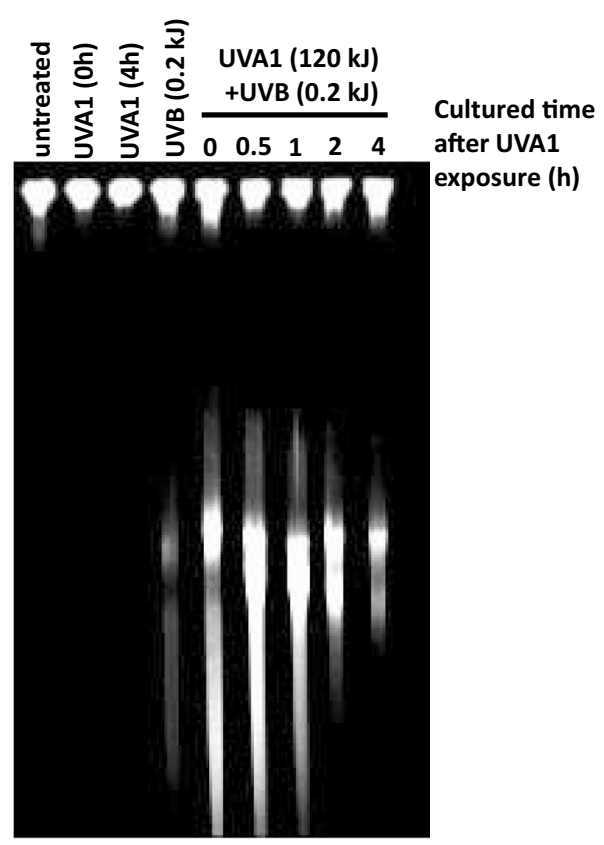

Fig. 4 DSB formation after coexposure to UVA1 and UVB. HaCaT cells cultured in low serum DMEM were irradiated with UVA1, followed by UVB irradiation. After further incubation for predefined periods, DSBs generated were detected by BSFGE. a Time-dependent formation of DSBs. After coexposure to UVA1 $\left(160 \mathrm{~kJ} / \mathrm{m}^{2}\right)$ and/ or UVB $\left(0.2 \mathrm{~kJ} / \mathrm{m}^{2}\right)$, HaCaT cells were cultured for up to $2 \mathrm{~h}$. b UVB- dose dependency. HaCaT cells pre-irradiated with UVA1 $\left(160 \mathrm{~kJ} / \mathrm{m}^{2}\right)$ were exposed to different doses of UVB (up to $0.3 \mathrm{~kJ} / \mathrm{m}^{2}$ ) and cultured for $2 \mathrm{~h}$. $\mathbf{c}$ The different DSBs formation dependent on interval between UVA1 and UVB exposure. HaCaT cells pre-irradiated with UVA1 $\left(120 \mathrm{~kJ} / \mathrm{m}^{2}\right)$ were cultured for predefined periods (up to $4 \mathrm{~h}$ ), then exposed to UVB $\left(0.2 \mathrm{~kJ} / \mathrm{m}^{2}\right)$ 
A

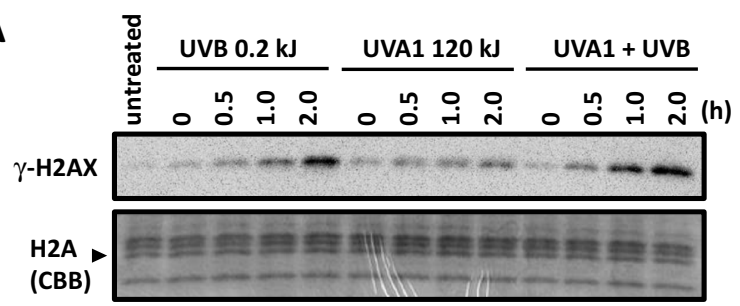

B

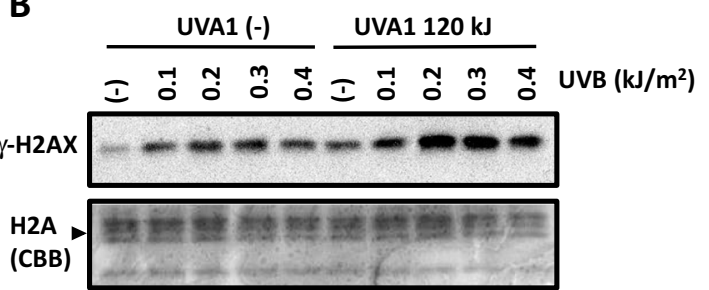

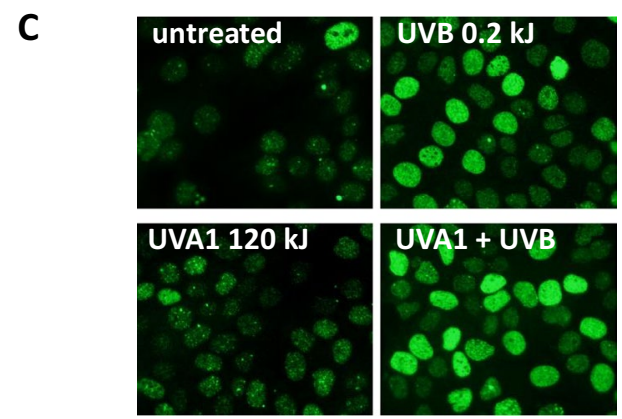

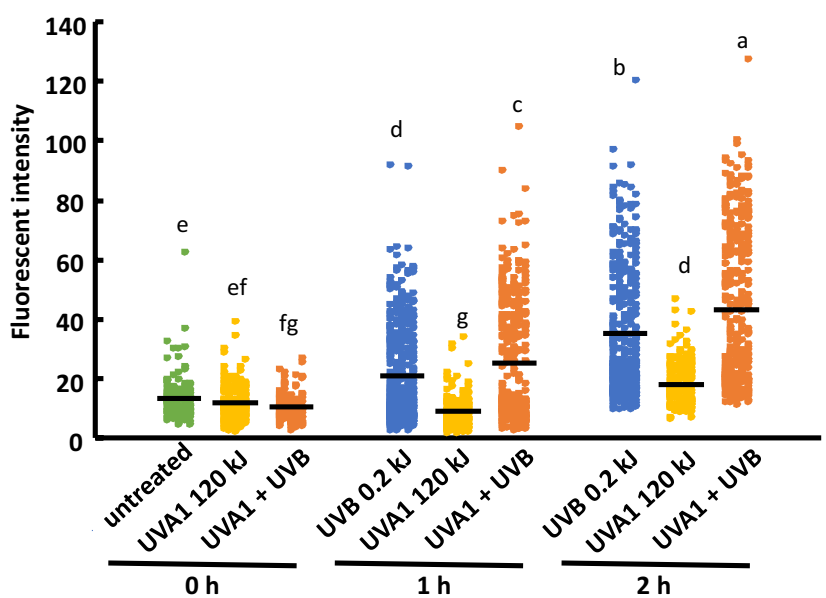

Fig. $5 \gamma$-H2AX induction after coexposure to UVA1 and UVB. a $\mathrm{HaCaT}$ cells cultured in low serum DMEM were irradiated with UVA1 $\left(120 \mathrm{~kJ} / \mathrm{m}^{2}\right)$, followed by UVB irradiation $\left(0.2 \mathrm{~kJ} / \mathrm{m}^{2}\right)$. After culture for up to $2 \mathrm{~h}$, the generation of $\gamma-\mathrm{H} 2 \mathrm{AX}$ was determined using western blotting. b HaCaT cells were irradiated with UVA1 (120 kJ/ $\mathrm{m}^{2}$ ), followed by UVB irradiation (up to $0.4 \mathrm{~kJ} / \mathrm{m}^{2}$ ). After culture for up to $2 \mathrm{~h}$, the generation of $\gamma-\mathrm{H} 2 \mathrm{AX}$ was determined. $\mathbf{c} \mathrm{HaCaT}$ cells were irradiated with UVA1 $\left(120 \mathrm{~kJ} / \mathrm{m}^{2}\right)$, followed by UVB irradiation

$\left(0.2 \mathrm{~kJ} / \mathrm{m}^{2}\right)$. After culture for up to $2 \mathrm{~h}$, immunofluorescence staining was performed for $\gamma-\mathrm{H} 2 \mathrm{AX}$. The nucleus was stained with PI $(1 \mu \mathrm{g} /$ $\mathrm{mL}$ ). The images were randomly taken (5 pictures), and the fluorescent intensity of each cells in nuclei was calculated [about 150 cells per sample were evaluated $(n=5)]$. Different letters indicate significant differences between groups (post-hoc Student's $t$ test with Bonferroni correction, $p<0.05$ )
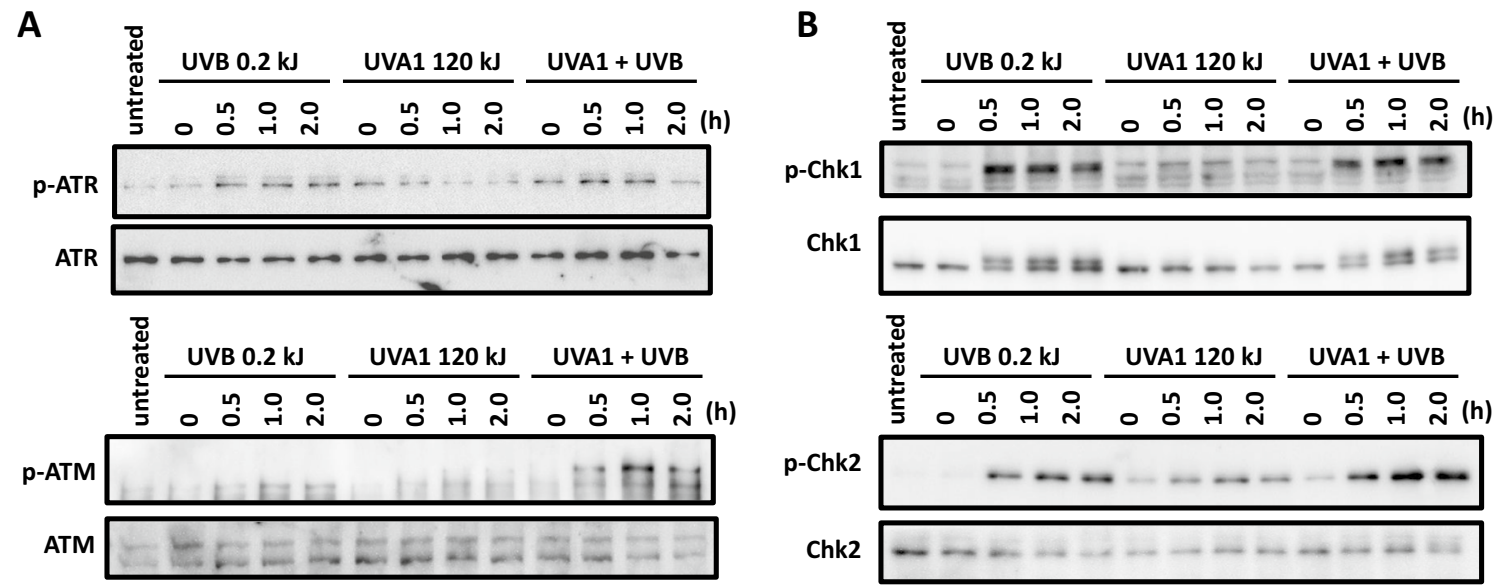

Fig. 6 Activation of ATR-Chk1 and ATM-Chk2 pathways after coexposure to UVA1 and UVB. HaCaT cells cultured in low serum DMEM were irradiated with UVA1 $\left(120 \mathrm{~kJ} / \mathrm{m}^{2}\right)$, followed by UVB

irradiation $\left(0.2 \mathrm{~kJ} / \mathrm{m}^{2}\right)$. After further incubation for up to $2 \mathrm{~h}$, a p-ATM and p-ATR, b p-Chk1 and p-Chk2 were detected by western blotting 
oxidized repair proteins, which impaired the repair of pyrimidine dimers. In this study, we evaluated TFIIH, XPG and XPA using local irradiation method [29], and found that accumulation and release of these proteins were remarkably delayed. TFIIH and XPA are DNA repair proteins reported to be targeted by oxidation [38]. Although we did not analyze RPA in this study, RPA is also a target of oxidation [38] and its function might be impaired by UVA1 irradiation [39]. UVA radiation has been shown to produce CPDs [5, 6], which means that UVA irradiation by itself can induce both pyrimidine dimers and protein oxidative damage, similar to combined exposure to UVA and UVB. However, UVA1induced CPDs would be only marginal compared to UVBinduced CPDs as shown in Fig. 2. Therefore, UVA1 alone would not cause drastic cell death. As proteins related to NER and BER are reported to interact with each other [40], the repair of oxidative DNA damage besides pyrimidine dimers also might be compromised by UVA1-induced oxidation of repair molecules.

ssDNA gaps are generated after the incision of nucleotides containing pyrimidine dimers. The gap-filling speed determined by EdU assay was also delayed by UVA1 preirradiation. Proliferating Cell Nuclear Antigen (PCNA), which acts for gap filling with DNA polymerase, is a target of oxidative stress [38]. PCNA is reported to cross-link with other proteins by UVA irradiation. The remaining ssDNA gaps initiate $\gamma$-H2AX via ATR pathway [19, 41]. In Fig. 5, $\gamma$-H2AX was enhanced by combined exposure. We first considered the possibility that the enhanced $\gamma-\mathrm{H} 2 \mathrm{AX}$ was due to unfilled ssDNA gaps, but p-ATR and p-Chk1, which are known to be activated by SSBs [32], were not augmented by combined exposure in Fig. 6. On the other hand, p-ATM and p-Chk2, which are known to be activated by DSBs [32], were enhanced by combined exposure. These suggested that DSBs were induced by combined exposure.

To confirm the formation of DSBs, we directly detected DNA fragmentation by BSFGE in Fig. 4. Both UVA and UVB irradiation generated slight amounts of DSBs, whereas combined exposure induced remarkable formation of DSBs.

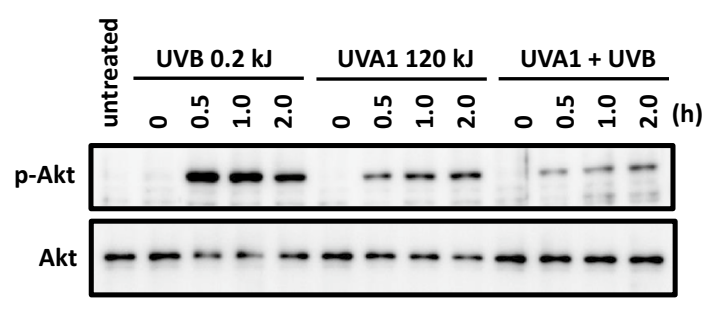

Fig. 7 Inhibition of Akt pathway after coexposure to UVA1 and UVB. HaCaT cells cultured in low serum DMEM were irradiated with UVA1 $\left(120 \mathrm{~kJ} / \mathrm{m}^{2}\right)$, followed by UVB irradiation $\left(0.2 \mathrm{~kJ} / \mathrm{m}^{2}\right)$. After further incubation for up to $2 \mathrm{~h}$, p-Akt was detected by western blotting
A cause of DSBs formation after UV irradiation is blocked replication forks [16, 31]. Furthermore, DSBs arise during the repair of bi-stranded, clustered DNA lesions [12]. The simultaneous excision of nearby lesions of bi-stranded DNA by BER and NER can produce DSBs [17]. Combined exposure of UVA1 and UVB can simultaneously induce pyrimidine dimers and oxidative DNA lesions as well as oxidative damage of repair proteins. This mixed DNA damage formation and incomplete DNA damage repair may have resulted in the enhanced DSBs formation after the combined exposure.

As another reason for remarkable cell death after combined exposure other than the formation of DSBs, attenuation of PI3K/Akt survival pathway was considered. Phosphorylation of Akt by UVB was decreased by UVApreirradiation (Fig. 7). The PI3K/Akt survival pathway is well known to be activated by UVB irradiation in human skin [42], but the suppression by combined irradiation with UVA has not been demonstrated. Oxidation of several proteins by UVA as described above probably compromised the survival pathways in cells irradiated with UVA1 and UVB. The inhibition of UVB-induced apoptotic cell death by preirradiation of UVA1 (Fig. 1c) could also be explained by a similar reason; apoptotic pathway could not be normally executed due to UVA1-mediated oxidation. Thus, the observed enhanced cell death by combined exposure was most likely driven by necrotic cell death. On the other hand, apoptosis induction after UVB exposure was not influenced by UVA1 exposure in melanocytes [35]. In mouse skin, UVA1 exposure decreased sunburn cells and caspase-3 activity [27]. These discrepancies might be due to experimental conditions such as the ratios of UVA to UVB, and cell lines.

Cell death is an important process to eliminate damaged cells. Remarkable cell death by combined exposure to UVA and UVB observed in Fig. 1 could be beneficial in eliminating cells with excessive DNA damage thereby suppressing mutation. Still, mutation risk by combined UVA and UVB is reported to be higher than the same doses delivered separately [36]. Even if the apoptotic process can eliminate part of the cells with excessive DNA damage, surviving cells are loaded with the excess formation of DSBs plus pyrimidine dimers after coexposure to UVA1 and UVB, which might result in the enhanced mutation risk. On the other hand, in an in vivo study using solar-simulated UVR, increasing doses of UVA1 to UVB decreased both the sunburn cell and caspase-3-positive cell number [27]. This was dependent on carbon monoxide production via UVA1-induced heme oxygenase-1 [43]. Some photoprotective actions of heme oxygenase-1 induced after UVA irradiation have been discussed [44, 45]. In this study, it is most likely that the damage induced by high doses of UVA1 overwhelmed the protective effect and resulted in the augmented cell death. In addition, 
$\mathrm{HaCaT}$ used in this study is p53 null cell line and might be different from normal cells in response to UV [46]. UVA is classified as a Class I carcinogen [1], but whether UVA1 acts as an enhancer or suppressor of mutation risk of UVB has not been clarified. The doses of UVA1 and ratio to UVB may be the important player to mediate the risk, which warrants further investigation in the physiological skin environment.

The incubation for $6 \mathrm{~h}$ after UVA1 irradiation reversed the enhanced cell death to the original level of cell death induced by UVB exposure alone (Supplementary Fig. 4). The DSBs formation detected by BSFGE was also recovered by irradiation with an interval of $4 \mathrm{~h}$ between UVA1 and UVB (Fig. 4c). These data mean that UVA1-induced damages are transient and recoverable. Graindoge et al. [47] reported that singlet oxygen produced after UVA irradiation inhibited replication fork progression, which was recovered after $5 \mathrm{~h}$. As the irradiated doses of UVA used by Graindoge et al. [47] were almost the same as this study, the required time for recovery is expected to be close to $5 \mathrm{~h}$. Singlet oxygen causes oxidative damage to the important proteins for DNA replication and repair [48]. Therefore, enhanced cell death and DSBs formation observed after coexposure to UVA1 and UVB might be caused by singlet oxygen produced by UVA1 irradiation.

\section{Conclusions}

Combined exposure to high doses of UVA1 and UVB resulted in drastic enhancement of cell death regardless of the sequence. The combination of these UV irradiation seemed to have caused suppressed NER activity and the formation of the most deleterious form of DNA damage, DSBs. These results suggested the risk of simultaneous exposure to high doses of UVA1 with UVB. The UVA dose is usually stronger than UVB (15 times stronger in natural sunlight in early spring in Sydney [30]), and UVA1 dose ratios to UVB used in this study are much higher than what we are normally exposed to. In addition, the exposure to humans is not sequential as in our study but simultaneous. However, the incorrect use of sunscreens, artificial tanning equipment, and sunlight-irradiation in the presence of photosensitizing agents could produce ample quantities of singlet oxygen that inhibit the repair of UVB-induced damage as demonstrated in this study. Excess oxidation definitely would inhibit the repair process of UVB-induced damage and may lead to the most serious form of DNA damage, DSBs.

Supplementary Information The online version contains supplementary material available at https://doi.org/10.1007/s43630-021-00050-w.
Acknowledgements We are grateful to Dr. Vivienne Reeve (University of Sydney) for giving us an excellent suggestion for this research. We also thank Mr. Takuto Okuya for his experimental assistance. This work was supported by Shiseido Female Researcher Science Grant.

\section{Declarations}

Conflict of interest None declared.

\section{References}

1. El Ghissassi, F., Baan, R., Straif, K., Grosse, Y., Secretan, B., Bouvard, V., Benbrahim-Tallaa, L., Guha, N., Freeman, C., Galichet, L., \& Cogliano, V. (2009). A review of human carcinogensPart D: radiation. The Lancet. Oncology, 10(8), 751-752

2. Cadet, J., \& Douki, T. (2018). Formation of UV-induced DNA damage contributing to skin cancer development. Photochemical and Photobiological Sciences, 17(12), 1816-1841

3. Mouret, S., Charveron, M., Favier, A., Cadet, J., \& Douki, T. (2008). Differential repair of UVB-induced cyclobutane pyrimidine dimers in cultured human skin cells and whole human skin. DNA Repair (Amst), 7(5), 704-712

4. Courdavault, S., Baudouin, C., Sauvaigo, S., Mouret, S., Candéias, S., Charveron, M., Favier, A., Cadet, J., \& Douki, T. (2004). Unrepaired cyclobutane pyrimidine dimers do not prevent proliferation of UV-B-irradiated cultured human fibroblasts. Photochemistry and Photobiology, 79(2), 145-151

5. Mouret, S., Baudouin, C., Charveron, M., Favier, A., Cadet, J., \& Douki, T. (2006). Cyclobutane pyrimidine dimers are predominant DNA lesions in whole human skin exposed to UVA radiation. Proceedings of the National Academy of Sciences of the United States of America, 103(37), 13765-13770

6. Ikehata, H., Kawai, K., Komura, J., Sakatsume, K., Wang, L., Imai, M., Higashi, S., Nikaido, O., Yamamoto, K., Hieda, K., Watanabe, M., Kasai, H., \& Ono, T. (2008). UVA1 genotoxicity is mediated not by oxidative damage but by cyclobutane pyrimidine dimers in normal mouse skin. The Journal of Investigative Dermatology, 128(9), 2289-2296

7. Mouret, S., Philippe, C., Gracia-Chantegrel, J., Banyasz, A., Karpati, S., Markovitsi, D., \& Douki, T. (2010). UVA-induced cyclobutane pyrimidine dimers in DNA: a direct photochemical mechanism? Organic and Biomolecular Chemistry, 8(7), 1706-1711

8. Ikehata, H. (2018). Mechanistic considerations on the wavelengthdependent variations of UVR genotoxicity and mutagenesis in skin: The discrimination of UVA-signature from UV-signature mutation. Photochemical and Photobiological Sciences, 17(12), 1861-1871

9. Kappes, U. P., \& Rünger, T. M. (2005). No major role for 7,8-dihydro-8-oxoguanine in ultraviolet light-induced mutagenesis. Radiation Research, 164(4 Pt 1), 440-445

10. Premi, S., Wallisch, S., Mano, C. M., Weiner, A. B., Bacchiocchi, A., Wakamatsu, K., Bechara, E. J., Halaban, R., Douki, T., \& Brash, D. E. (2015). Photochemistry. Chemiexcitation of melanin derivatives induces DNA photoproducts long after UV exposure. Science (New York, NY), 347(6224), 842-847

11. Schuch, A. P., Moreno, N. C., Schuch, N. J., Menck, C. F. M., \& Garcia, C. C. M. (2017). Sunlight damage to cellular DNA: Focus on oxidatively generated lesions. Free Radical Biology and Medicine, 107, 110-124

12. Greinert, R., Volkmer, B., Henning, S., Breitbart, E. W., Greulich, K. O., Cardoso, M. C., \& Rapp, A. (2012). UVA-induced DNA double-strand breaks result from the repair of clustered oxidative DNA damages. Nucleic Acids Research, 40(20), 10263-10273 
13. Rapp, A., \& Greulich, K. O. (2004). After double-strand break induction by UV-A, homologous recombination and nonhomologous end joining cooperate at the same DSB if both systems are available. Journal of Cell Science, 117(Pt 21), 4935-4945

14. Garinis, G. A., Mitchell, J. R., Moorhouse, M. J., Hanada, K., de Waard, H., Vandeputte, D., Jans, J., Brand, K., Smid, M., van der Spek, P. J., Hoeijmakers, J. H., Kanaar, R., \& van der Horst, G. T. (2005). Transcriptome analysis reveals cyclobutane pyrimidine dimers as a major source of UV-induced DNA breaks. EMBO Journal, 24(22), 3952-3962

15. Ward, I. M., \& Chen, J. (2001). Histone H2AX is phosphorylated in an ATR-dependent manner in response to replicational stress. Journal of Biological Chemistry, 276(51), 47759-47762

16. Halicka, H. D., Huang, X., Traganos, F., King, M. A., Dai, W., \& Darzynkiewicz, Z. (2005). Histone H2AX phosphorylation after cell irradiation with UV-B: Relationship to cell cycle phase and induction of apoptosis. Cell Cycle, 4(2), 339-345

17. Cannan, W. J., Tsang, B. P., Wallace, S. S., \& Pederson, D. S. (2014). Nucleosomes suppress the formation of double-strand DNA breaks during attempted base excision repair of clustered oxidative damages. Journal of Biological Chemistry, 289(29), 19881-19893

18. Eccles, L. J., Lomax, M. E., \& O'Neill, P. (2010). Hierarchy of lesion processing governs the repair, double-strand break formation and mutability of three-lesion clustered DNA damage. Nucleic Acids Research, 38(4), 1123-1134

19. Matsumoto, M., Yaginuma, K., Igarashi, A., Imura, M., Hasegawa, M., Iwabuchi, K., Date, T., Mori, T., Ishizaki, K., Yamashita, K., Inobe, M., \& Matsunaga, T. (2007). Perturbed gap-filling synthesis in nucleotide excision repair causes histone $\mathrm{H} 2 \mathrm{AX}$ phosphorylation in human quiescent cells. Journal of Cell Science, $120(\mathrm{Pt}$ 6), 1104-1112

20. Ray, A., Blevins, C., Wani, G., \& Wani, A. A. (2016). ATR- and ATM-mediated DNA damage response is dependent on excision repair assembly during G1 but not in S phase of cell cycle. PLoS ONE, 11(7), e0159344

21. Courdavault, S., Baudouin, C., Charveron, M., Canguilhem, B., Favier, A., Cadet, J., \& Douki, T. (2005). Repair of the three main types of bipyrimidine DNA photoproducts in human keratinocytes exposed to UVB and UVA radiations. DNA Repair (Amst), 4(7), 836-844

22. Runger, T. M. (2007). How different wavelengths of the ultraviolet spectrum contribute to skin carcinogenesis: the role of cellular damage responses. The Journal of Investigative Dermatology, 127(9), 2103-2105

23. Talve, L., Stenbäck, F., \& Jansén, C. T. (1990). UVA irradiation increases the incidence of epithelial tumors in UVB-irradiated hairless mice. Photodermatology, Photoimmunology and Photomedicine, 7(3), 109-115

24. Willis, I., Menter, J. M., \& Whyte, H. J. (1981). The rapid induction of cancers in the hairless mouse utilizing the principle of photoaugmentation. The Journal of Investigative Dermatology, 76(5), 404-408

25. Bech-Thomsen, N., Poulsen, T., Christensen, F. G., Lundgren, K., \& Wulf, H. C. (1994). Near-visible-UV radiation delays UVB tumorigenesis. Journal of Photochemistry and Photobiology B: Biology, 22(2), 119-123

26. Reeve, V. E., Domanski, D., \& Slater, M. (2006). Radiation sources providing increased UVA/UVB ratios induce photoprotection dependent on the UVA dose in hairless mice. Photochemistry and Photobiology, 82(2), 406-411

27. Ibuki, Y., Allanson, M., Dixon, K. M., \& Reeve, V. E. (2007). Radiation sources providing increased UVA/UVB ratios attenuate the apoptotic effects of the UVB waveband UVA-dose-dependently in hairless mouse skin. The Journal of Investigative Dermatology, 127(9), 2236-2244
28. Ibuki, Y., \& Goto, R. (2000). Suppression of apoptosis by UVB irradiation: survival signaling via PI3-kinase/Akt pathway. Biochemical and Biophysical Research Communications, 279(3), 872-878

29. Katsumi, S., Kobayashi, N., Imoto, K., Nakagawa, A., Yamashina, Y., Muramatsu, T., Shirai, T., Miyagawa, S., Sugiura, S., Hanaoka, F., Matsunaga, T., Nikaido, O., \& Mori, T. (2001). In situ visualization of ultraviolet-light-induced DNA damage repair in locally irradiated human fibroblasts. The Journal of Investigative Dermatology, 117(5), 1156-1161

30. Halliday, G. M., \& Rana, S. (2008). Waveband and dose dependency of sunlight-induced immunomodulation and cellular changes. Photochemistry and Photobiology, 84, 35-46

31. Cleaver, J. E. (2011). gammaH2Ax: Biomarker of damage or functional participant in DNA repair "all that glitters is not gold!" Photochemistry and Photobiology, 87(6), 1230-1239

32. Smith, J., Tho, L. M., Xu, N., \& Gillespie, D. A. (2010). The ATM-Chk2 and ATR-Chk1 pathways in DNA damage signaling and cancer. Advances in Cancer Research, 108, 73-112

33. Scharer, O. D. (2013). Nucleotide excision repair in eukaryotes. Cold Spring Harbor Perspectives in Biology, 5(10), a012609

34. Krokan, H. E., \& Bjoras, M. (2013). Base excision repair. Cold Spring Harbor Perspectives in Biology, 5(4), a012583

35. Kimeswenger, S., Dingelmaier-Hovorka, R., Foedinger, D., \& Jantschitsch, C. (2018). UVA1 impairs the repair of UVB-induced DNA damage in normal human melanocytes. Experimental Dermatology, 27(3), 276-279

36. McAdam, E., Brem, R., \& Karran, P. (2016). Oxidative stressinduced protein damage inhibits DNA repair and determines mutation risk and therapeutic efficacy. Molecular Cancer Research, 14(7), 612-622

37. Brem, R., Macpherson, P., Guven, M., \& Karran, P. (2017). Oxidative stress induced by UVA photoactivation of the tryptophan UVB photoproduct 6-formylindolo[3,2- $b]$ carbazole (FICZ) inhibits nucleotide excision repair in human cells. Science and Reports, $7(1), 4310$

38. Karran, P., \& Brem, R. (2016). Protein oxidation, UVA and human DNA repair. DNA Repair (Amst), 44, 178-185

39. Guven, M., Brem, R., Macpherson, P., Peacock, M., \& Karran, P. (2015). Oxidative damage to RPA limits the nucleotide excision repair capacity of human cells. The Journal of Investigative Dermatology, 135(11), 2834-2841

40. Kumar, N., Moreno, N. C., Feltes, B. C., Menck, C. F., \& Houten, B. V. (2020). Cooperation and interplay between base and nucleotide excision repair pathways: From DNA lesions to proteins. Genetics and Molecular Biology, $43(1$ suppl. 1), e20190104

41. Hanasoge, S., \& Ljungman, M. (2007). H2AX phosphorylation after UV irradiation is triggered by DNA repair intermediates and is mediated by the ATR kinase. Carcinogenesis, 28(11), 2298-2304

42. Bowden, G. T. (2004). Prevention of non-melanoma skin cancer by targeting ultraviolet-B-light signalling. Nature Reviews Cancer, 4(1), 23-35

43. Allanson, M., \& Reeve, V. E. (2005). Ultraviolet A (320-400 nm) modulation of ultraviolet B (290-320 nm)-induced immune suppression is mediated by carbon monoxide. The Journal of Investigative Dermatology, 124(3), 644-650

44. Tyrrell, R. M., \& Reeve, V. E. (2006). Potential protection of skin by acute UVA irradiation-From cellular to animal models. Progress in Biophysics and Molecular Biology, 92(1), 86-91

45. Xiang, Y., Liu, G., Yang, L., \& Zhong, J. L. (2011). UVA-induced protection of skin through the induction of heme oxygenase-1. Bioscience Trends, 5(6), 239-244

46. Henseleit, U., Zhang, J., Wanner, R., Haase, I., Kolde, G., \& Rosenbach, T. (1997). Role of p53 in UVB-induced apoptosis in 
human HaCaT keratinocytes. The Journal of Investigative Dermatology, 109(6), 722-727

47. Graindorge, D., Martineau, S., Machon, C., Arnoux, P., Guitton, J., Francesconi, S., Frochot, C., Sage, E., \& Girard, P. M. (2015). Singlet oxygen-mediated oxidation during UVA radiation alters the dynamic of genomic DNA replication. PLOS ONE, 10(10), e0140645

\section{Authors and Affiliations}

\section{Yuko Ibuki ${ }^{1} @$ - Yukako Komaki ${ }^{1}$. Guang Yang ${ }^{1}$. Tatsushi Toyooka ${ }^{2}$}

Yuko Ibuki

ibuki@u-shizuoka-ken.ac.jp

1 Graduate Division of Nutritional and Environmental

Sciences, University of Shizuoka, 52-1 Yada,

Shizuoka 422-8526, Japan
48. Montaner, B., O’Donovan, P., Reelfs, O., Perrett, C. M., Zhang, X., Xu, Y. Z., Ren, X., Macpherson, P., Frith, D., \& Karran, P. (2007). Reactive oxygen-mediated damage to a human DNA replication and repair protein. EMBO Reports, 8(11), 1074-1079
2 National Institute of Occupational Safety and Health, Kawasaki, Japan 